\title{
The act of playing as a signifier for the application of the dramatic Therapeutic Toy performed by the nurse: theoretical reflection
}

\author{
O brincar como significante para aplicação do Brinquedo Terapêutico dramático pelo enfermeiro: reflexão teórica \\ El jugar como significante para aplicación del juguete terapéutico dramático por el enfermero: reflexión teórica
}

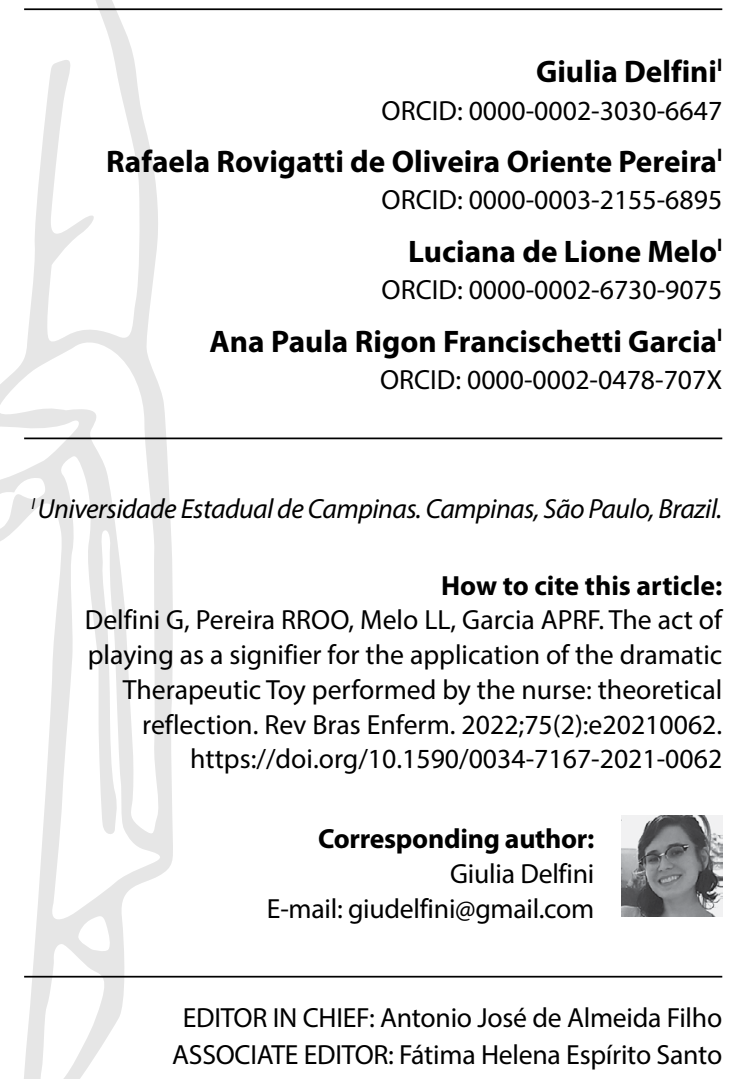

Submission: $03-01-2021$

\section{ABSTRACT}

Objective: To reflect on the possible contributions of the act of playing as a signifier in the use of dramatic Therapeutic Toy performed by the nurse. Methods: Theoretical-reflexive study, based on three moments: The language of the unconscious that emerges as a signifier when playing; How the dramatic Therapeutic Toy is used by the nurse; and the act of playing as a signifier during the application of the dramatic Therapeutic Toy: contributions to nursing practice. Results: Through the intervention of the nurse in the sessions, the act of playing mediated by the dramatic Therapeutic Toy provides the child with the opportunity to elaborate on signifier elements that had not been meant by him. Final considerations: Through the dramatic Therapeutic Toy, the articulation of the child's organism with his reality in the formation of the self constitutes an advance for the production of knowledge and nursing assistance to the child, enabling complete care and allowing the elaboration of their anxieties, which collaborates so that the child constitutes himself as a subject.

Descriptors: Nursing; Pediatric Nursing; Child; Play and Playthings; Psychoanalysis.

\section{RESUMO}

Objetivo: Refletir sobre possíveis contribuições do brincar enquanto significante na utilização do Brinquedo Terapêutico dramático na atuação do enfermeiro. Métodos: Estudo teóricoreflexivo, ancorado em três momentos: A linguagem do inconsciente que emerge no brincar como significante; Como o Brinquedo Terapêutico dramático é utilizado pelo enfermeiro; e $\mathrm{O}$ brincar enquanto significante no decorrer da aplicação do Brinquedo Terapêutico dramático: contribuições para a prática de enfermagem. Resultados: Por intermédio do manejo das sessões pelo enfermeiro, o brincar mediado pelo Brinquedo Terapêutico dramático proporciona à criança a oportunidade de elaboração de elementos significantes que não haviam sido significados por ela. Considerações finais: Mediante o Brinquedo Terapêutico dramático, a articulação do organismo da criança com sua realidade na formação do eu constitui avanço para produção de conhecimento e assistência de enfermagem à criança, possibilitando cuidado integral e permitindo a elaboração de suas angústias, o que colabora para que a criança se constitua enquanto sujeito. Descritores: Enfermagem; Enfermagem Pediátrica; Criança; Jogos e Brinquedos; Psicanálise.

\section{RESUMEN}

Objetivo: Reflejar posibles contribuciones del jugar mientras significante en la utilización del Juguete Terapéutico dramático en la actuación del enfermero. Métodos: Estudio teóricoreflexivo, ancorado en tres momentos: Lenguaje del inconsciente que emerge en el jugar como significante; Como el Juguete Terapéutico dramático es utilizado por el enfermero; y El jugar mientras significante en transcurso de la aplicación del Juguete Terapéutico dramático: contribuciones a práctica de enfermería. Resultados: Por intermedio del manejo de sesiones por el enfermero, el jugar mediado por Juguete Terapéutico dramático proporciona al niño la oportunidad de elaboración de elementos significantes que no le habían sido significados. Consideraciones finales: Mediante Juguete Terapéutico dramático, la articulación del organismo del niño con su realidad en su formación del yo constituye avanzo para producción de conocimiento y asistencia de enfermería pediátrica, posibilitando cuidado integral y permitiendo la elaboración de sus angustias, que colabora para que el niño se constituya mientras sujeto. Descriptores: Enfermería; Enfermería Pediátrica; Niños; Juego e Implementos de Juego; Psicoanálisis. 


\section{INTRODUCTION}

The act of playing is a child's right, one of the most important childhood activities, which stimulates him in its social, physical, and intellectual dimensions, and through it the child learns and develops himself(1). Through the toy and its playful action, the child becomes able to express reality, building and deconstructing a meaningful world that corresponds to the essential needs for development ${ }^{(1)}$.

In health care, the act of playing as a therapeutic activity reduces the emotional suffering of children and helps them cope with clinical experiences and can be used in daily care routines ${ }^{(2-3)}$. Since pediatric nursing care must ensure full attention to the child, it is necessary to include the act of playing in the care through the use of the toy by the nurse, aiming at all therapeutic purposes that it provides ${ }^{(1)}$.

The Federal Council of Nursing, following Resolution No. $546 / 2017$, recognizes the Therapeutic Toy (TT) as an activity carried out by nursing, stating that the nurse that works in the pediatric section can decide to use or not the TT in the care of hospitalized children ${ }^{(1)}$. The TT, recognized in the scientific literature since 1980, is described as a structured toy to alleviate the anxieties of the child generated by experiences atypical to his age, being classified into three modalities: dramatic or cathartic, instructional, and enabler of physiological functions $s^{(3)}$.

The reflection that we present refers to the dramatic TT since it enables the nurse to better understand the child's needs, helping her to elaborate previous or imminent feelings; contributing to the construction of the therapeutic relationship with child and family; and encouraging participation in care ${ }^{(3)}$. In addition, together with adequate communication, it promotes the planning and creation of coping and management strategies ${ }^{(3)}$. Therefore, the dramatic TT used by nursing helps in the creation and maintenance of emotional, social, and behavioral skills, in addition to reducing fear and anxiety levels, improving communication and self-esteem ${ }^{(2)}$.

The act of playing is a type of language in which the nurse recognizes the process the child elaborates anxieties generated by atypical experiences ${ }^{(3)}$ through the appropriate reading of the child's relationship with the toy, that is, it is necessary to read the act of play having theoretical bases, which favors its transformation into therapeutic. Therefore, when we consider the relationship between child and toy during the play, we can recognize the care needs ${ }^{(3)}$, and it can be used by the nurse to implement individualized care ${ }^{(2)}$.

Psychoanalysis offers a possibility of theoretical reading in which a toy is an object, and, by manipulating it, the child establishes relationships to compose a symbolism, which constitutes and evidences traits of his subjectivity ${ }^{(4)}$. Therefore, from the perspective of psychoanalysis, although the child has limitations in verbalization, he can make free associations through the act of playing, acting out, as a way to repeat or act what cannot be remembered, making repetition a possibility of elaboration ${ }^{(5)}$.

Therefore, when the nurse assumes the reading of playing considering the relationship of object, in which the child takes it as a signifier that can be understood in this relationship between him and the toy, the importance of the act of playing for the subjective constitution is recognized ${ }^{(4,6)}$. So, it is essential to direct nursing care to subsidize the nurse's reading so that the nurse relates to the child and can identify care needs in the act of play. Thus, the present work aims to reflect on the possible contributions of the act of playing as a signifier in the use of the technique of dramatic TT in the performance of nurses.

From the methodological point of view, this theoretical reflection is structured in three topics. The first topic aims to clarify essential concepts to understand how the language of the unconscious emerges in the act of playing as signifier. The second has the purpose of exposing the mode by which the dramatic TT has been used by the nurse. And, finally, the third topic aims to lead the reflection on how the nurse can apply the dramatic TT in the care of the child considering the act of playing as a signifier.

\section{The language of the unconscious that emerges in the act of playing as signifier}

For the nurse to be able to use the conception of the act of playing as a structuring of the human psyche and recognize the toy in his relationship with the child, it is necessary to present concepts that will base such reading.

Language is a complex of relations between meaning and signifier, and it consists of a phonemic unit, that is, the concrete discourse, which is not present only to exert a single meaning but to provide multiple meanings, which have the function of representing a subject to another signifier in chain ${ }^{(6)}$. It is, therefore, the unconscious manifestation, which repeats itself and is part of the individual, group, and social, not being the property of someone and passing through each one ${ }^{(4)}$. A signifier, when instituted, creates something new in the continuity of the subject's experience ${ }^{(4,6)}$.

At birth, the subject enters, through the language presented by his family, in a social order that is previous to him, being preceded by a familiar myth with signifiers that will name him, involving him into the language ${ }^{(4,6-7)}$. It happens because the baby will need a caregiver who will perform the role of interpreter, understood as the function of the Other, aspect that will establish demands and name the acts of the baby ${ }^{(6)}$. As far as this Other interprets the state of the child and tries to produce meanings capable of appeasing it, he is inserted into the logic of the language, represented by the signifiers offered to him $^{(8)}$.

This Other, responsible for inscribing the fundamental signifiers that will give entry to the baby's language, occupies the maternal function ${ }^{(8)}$ and contributes to the formation of a significant structure composed of signifier elements for the family and society in which this baby is inserted, that is, this Other helps to form the so-called family myth ${ }^{(4,7,10)}$. Therefore, the family social dimension is essential to the constitution of the subject of the unconscious since there is a system of pre-existing relations of significant order preceding it because the Other that precedes him is already taken by language ${ }^{(4-6)}$.

However, the family myth does not contemplate all the significance for structuring the subject, and the lack of response of the Other to the demand of the baby produces an empty place from which the desire acquires a signifier function ${ }^{(7)}$. Therefore, in addition to the signifiers offered by those who exercise the maternal function, there is a lack of meaning when the Other positions himself as unable to grant all possible meanings to the signifiers inherited by the baby ${ }^{(4)}$. 
It is common for the child to cling to a figure that was present in his family myth, discursively or physically, aiming to produce something to process the unconscious, that is, to respond to the situations that will be presented to him in the course of life in a regularly repeated way, as the external circumstances and the nature of the objects become accessible to him, which means the transferential process ${ }^{(4,6)}$. The transfer, in psychoanalysis, modifies the relations of the subject with his unconscious, being an update of the principle of reality, understood as the chain of signifiers of this subject in action ${ }^{(6)}$.

When playing, the child repeats situations that have caused impressions in his reality, becoming a more active dominator of the situation ${ }^{(4)}$, and this domination is strengthened with each new repetition, so we can understand the act of playing as a therapeutic activity ${ }^{(5)}$. There is no significant activity in the development of the child's symbolization that does not permeate the act of playing ${ }^{(4)}$ : the symbolic matrix happens before the subject is objectified in the dialectic of identification with the other and before the language restores his function as a subject ${ }^{(6)}$.

During the mirror stage, the moment when the baby establishes a relationship of his organism with reality, he recognizes his image, but it is not real but fairly illusory, a projection of the maternal desire concerning it, since it is the mother, in his gaze, that enables him to find a unified image of his body, the directions for the formation of his self ${ }^{(6)}$. This phenomenon illustrates the conflict of the dual relationship between subject and object, that is, subject and its representation, and all that the child apprehends in the captivity by his image is the distance between his internal tensions and the identification of his image, and between these there will always be a lack ${ }^{(6)}$.

The mother has a structural ignorance about the objects she offers to her child, and the transmission of her signifiers to him happens precisely by the relationship of the objects that will support the care and that favor the origin of the subject $t^{(4,6-7)}$. Therefore, it is possible to use the act of playing and seize the toy as an object in which the child can show its structure ${ }^{(5)}$.

Considering that the unconscious has a structure similar to a language and that this happens through signifiers, the act of playing becomes a form of language of access to the unconscious, an important practice having the toy as an object ${ }^{(4)}$. When playing, the child creates holes that allow the invention of bridges, that is, the act of playing brings the possibility of building symbolic elaborations ${ }^{(4)}$. Therefore, the child has holes, delimited by the mismatch between the organic conception and his reality, which should be filled by their constructions through the symbolic articulation, originally introduced by the maternal function and experienced by the child in the act of play ${ }^{(4,6)}$.

\section{How the dramatic therapeutic toy has been used by the nurse}

As mentioned, TT is a care technology that involves a technique with legal support for application in Nursing Care ${ }^{(1)}$. It is important to point out that the literature regarding dramatic TT in nurses' care practice focuses its attention primarily on Hospitalized Children. As for the application of TT in healthy children, studies are scarce ${ }^{(2)}$.

Nursing must ensure full attention to the child in any care environment, which includes the use of the act of playing - which is a child's right — to promote development ${ }^{(1)}$. Therefore, discussing the use of play, especially mediated by dramatic TT, as an instrument in nursing care allows us to understand how it is implemented within care practices, what are the gaps present in scientific production, and what evidence presents it as an efficient resource ${ }^{(1)}$.

The main benefits reported on the implementation of the dramatic TT by the nurse are: the humanization of care, ensuring safety in the care; building a bond between professional and child; improvement of social, emotional, behavioral, problem-solving, coping, and reasoning skills; control of the levels of fear, anxiety, anger, and aggression; the enhancement of self-esteem, tolerance, and self-control; expression of desires, emotions, fears, feelings, and lived experiences; relief from tensions and stress resulting from illness/hospitalization; facilitate the integrality of care, giving a new meaning for the disease; exposure of internalized social relations and roles; helps in interacting with the social environment; promotes a greater collaboration in the treatment, and the possibility of promoting health education ${ }^{(1-2,9)}$.

In the process of dramatic TT, we can observe four articulated steps: bonding, exploring, dramatizing, and play cessation ${ }^{(9)}$. During the construction of the nurse-patient relationship, the child observes the professional, internalizing the idea that this is a reliable adult to expose their thoughts, feelings, fears, and emotions because he respects him as well as his decisions ${ }^{(9)}$. For example, non-interference in the child's decisions during play represents a manifestation of respect for their choices, being an efficient form of interaction that contributes to the construction of the relationship ${ }^{(9)}$. Therefore, the concept that the child creates of the nurse is the result of a sequence of interactions ${ }^{(9)}$.

In the process of exploration, the child recovers in his memory previous symbols and builds connections, internally reflecting and reordering what he observes, then seeks new symbols to mediate his external activities, which directly influences his choices during play and the meanings he attributes to interactions with the hospital environment ${ }^{(9)}$. This moment contributes to minimizing the anxiety, stress, and fears that the environment may cause ${ }^{(9)}$.

An essential function of dramatic TT is precisely the dramatization of roles, conflicts, and catharsis ${ }^{(9)}$. It allows the child to represent his desires or imitate real circumstances that afflict, frighten, distress, or impress them, being an articulation between the real and imaginary situation, evidencing the meaning that the real circumstances have for him to understand it and (re)signify $\mathrm{it}^{(9)}$. Therefore, when playing, he feels free to create, expressing his being, and mastering the situation in such a way that he can find solutions to the problems that afflict him.

Therefore, play is an activity in which the child, who has not yet fully acquired his cognitive and verbal abilities, can freely express himself. The use of TT as a nursing care strategy promotes specific and systematized care, promoting the articulation between science and practice ${ }^{(1-2)}$.

\section{The act of playing as a signifier in the course of the ap- plication of the dramatic Therapeutic Toy: contributions to nursing practice}

The dramatic TT, interpreted as a signifier, can offer a direction to the nurse to carry out the care of the child, contemplating his 
subjective traits and his family myth. For this, it is necessary to identify the context of this child, who, most of the time, is accompanied by his mother or another family member, and it makes him feel protected, supported, and comforted, having an individual by his side as a facilitator of his interactions and speaker for his needs, that is, facilitating the bond with his family ${ }^{(7,9)}$.

Therefore, in nursing care, the family is seen as a facilitator. Unconsciously, the family is also important because it governs fundamental processes of psychic development, essential for the baby to have a chance of survival ${ }^{(10)}$. One of the conflicts experienced by him is the complex of weaning, an essential process in which he will receive a psychic expression of a previously known weaning when he was separated from his mother at birth ${ }^{(10)}$. This weaning will cause a malaise impossible to be buffered by post-birth care ${ }^{(10)}$.

Therefore, the weaning complex leaves a permanent mark on the psyche of the baby due to the disruption with the biological functions of lactation, founding the most primitive and stable feelings that conjugate him to his family ${ }^{(10)}$. However, this process contributes to the development of the self, located in the mirror stage, which originates the relationship between the biologically assumed organism and its reality ${ }^{(6,10)}$. The individual who does not seek recognition outside the family context does not reach the formation of the self, and, in this case, the weaning complex becomes a mortal factor ${ }^{(6,10)}$.

We can expect that the mother, or another family member who accompanies him, remains most of the time of the TT session with the child, and often there may be interference in the play, either directly, suggesting toys, or indirectly, just by looking for his gaze by the child to be allowed to play.

Since the first relationship between the child's organism and its reality, during the mirror stage, occurs through the recognition of its own illusory image as a projection of maternal desire, this search is already expected. The nurse, recognizing the movement of the child and the mother/family member through the transferential relationship, needs to identify a possibility of suspending this search for constant authorization, favoring the child to play freely to elaborate and create meaning to the situations experienced, directing the constitution of an autonomous self $f^{(4,7)}$. This suspension, accompanied by the free play, also helps the child not to be paralyzed by the anguish of separation inherent in the process of caring for the hospitalized child, which contributes to creating the absence necessary for the constitution of the subject.

In the dramatic TT, a relationship is established between the child and the nurse, and if the act of playing is considered a signifier, this relationship becomes transferential. Thus, the professional becomes able to recognize the physical and mental needs of the child and, then, conducts the play offering assistance so that he can elaborate questions arising from hospitalization.

During play, the child, through dramatization, can transfer to the nurse the function of a great Other, the one who will offer him conditions to create signifiers ${ }^{(8)}$. Nurses need to be properly subsidized from a theoretical point-of-view to accomplish this function, know the appropriate time when they should favor this relationship and when to interrupt it, giving space to the absence. This is because it is between what is offered and what is missing that the child plays and builds bridges for symbolic elaborations, in the mismatch between his organism and his reality ${ }^{(6,8)}$.
In the transferential relationship during the act of playing, identification can also occur, a process in which the child identifies his own questions in the nurse and thus tries to fill them out. When he fills, he assumes the nurse as an object, and in this case, he is completing himself. Filling the other to fill yourself is one of the oldest forms of identification, dealing only with consuming the object to be filled ${ }^{(8)}$.

Still in this relationship, the child will present a request addressed to someone else ${ }^{(8)}$ who, in this case, will be the nurse. During the dramatic TT, as toys are offered to the child to establish object relations with them, this demand can be presented many times by the repetition of some play, or by the insistence with one of the toys since they are adopted as signifier objects. However, the repetition existing in the transferential relationship is always impossible to satisfy, which opens the possibility, by the insistence of repetition that tends to satisfaction, of new meanings to the signifier that is being handled, that is, the toy in the relationship between the child and the nurse. Therefore, the professional must receive the repeated insistence of the same play, with the same games and toys, because what is repeated tends to the symbolic elaboration by the very movement of repetition of the transferential relationship ${ }^{(4,6,8)}$.

Thus, in the dramatic TT, the equivalence between subject and object can be observed when the child repeats, in the act of playing, situations experienced in his hospitalization, such as when simulating, in the dolls, experiences of pain, suffering, and discomforts of the clinical daily. Therefore, although playful, play should not be interpreted only in this perspective ${ }^{(4)}$, which would reduce its therapeutic contribution. The act of playing is essential to aggregate information about the psychic and family situation of the child, giving the possibility of clarifying its context.

Since patients consist of meaning holes ${ }^{(4)}$, if the nurse fills them with his words or actions, he prevents the elaboration by the child, who does not participate in the interpretation of the experience, making the process ineffective. Therefore, the play should be managed by the nurse in to allow the child to create and interpret situations experienced, accessing the fantasy and filling his own holes, and this is the reason it should not be conducted by the professional.

The inclusion of holes in the act of playing can be adopted in the dramatic TT when the nurse allows the child to play freely, so that he can build his own play, choosing his objects. Furthermore, it is worth mentioning that this practice includes some contours, such as time and place, which favor the act of playing as an elaboration of his subjective passage since it establishes a continent and continuity ${ }^{(7)}$.

The concept of continuity is essential since it is imperative to create a routine with the child. For this, the nurse needs to assume a reliable and, at the same time, unpredictable posture ${ }^{(7)}$. Based on this, the dramatic TT should be a continuous practice if the child wishes because only then will she build a transference relationship with the nurse. Continuity favors the positivity of the act of playing of the child, and it is also related to the understanding of the nurse that such act is essential for the subjective constitution and, therefore, must be carried out and respected.

When the nurse manages the session, the act of playing mediated by the dramatic TT is an essential practice, which provides 
the child the opportunity to elaborate signifier elements hitherto not signified by him. For this, the act of playing must be free, if possible without family intervention, built on the transferential relationship with the nurse, and the nurse must conduct the play in such a way as not to fix meaning to it, leaving the child responsible for creating and interpreting the situations experienced. It is the way he creates his own symbolic elaborations and fill his holes with meaning.

\section{FINAL CONSIDERATIONS}

The dramatic TT, based on the theory defended here, can configure an important advance in knowledge since it allows the nurse to understand the articulation of the child's organism with its reality in the formation of the self to build an individual care plan that overcomes the need to elaborate events hitherto not experienced by her, enabling the offer of comprehensive care to the patient.

The act of playing managed by the nurse must be free because the family is considered as a source of conflict in its dialectical dimension of rapprochement and separation between child and family members, which emphasizes the importance of this activity in care. It allows the child to be able to elaborate and create meaning to the situations experienced, in addition, to avoid him to be paralyzed by the anguish of separation.

The nurse also needs to identify the transferential relationship that occurs between him and the child, which allows the conduct of the play so that it can elaborate its own questions. To make this elaboration possible, the nurse cannot seek the interpretation of the act of playing because the child's games has a chain of signifiers of its own. If the nurse gives meaning to its elements, he fixes a sense; and the fixation is not desirable because signifiers slide. The meaning needs to be given by the child, and the place of creation and interpretation of the situations lived must be exclusive to him so that he fills his holes with meaning.

Therefore, the reading of the act of playing while a signifier to the nurse in the session of dramatic TT is pertinent because when the child plays, he can release the anguish and elaborate them, thus constructing himself as an individual.

\section{REFERENCES}

1. Costa DTL, Veríssimo MLOR, Toriyama ATM, Sigaud CHS. O brincar na assistência de enfermagem à criança: revisão integrativa. Rev Soc Bras Enferm Ped. 2016;16(1):36-43. https://doi.org/10.31508/1676-3793201600005

2. Sezici E, Ocakci AF, Kadioglu H. Use of play therapy in nursing process: a prospective randomized controlled study. J Nurs Scholarsh. 2017;49(2):162-9. https://doi.org/10.1111/jnu.12277

3. Calegari T, Gimenes BP, Luz JH, Campos YAES, Borba RIH, Ribeiro CA. A criança autista em sessão de brinquedo terapêutico dramático: uma análise winnicottiana. Rev Soc Bras Enferm Ped. 2018;18(1):43-8. https://doi.org/10.31508/1676-3793201800007

4. Rodulfo R. O brincar e o significante: um estudo psicanalítico sobre a constituição precoce. Porto Alegre: Artes Médicas; 1990.179 p.

5. Leitão IB, Cacciari MB. A demanda clínica da criança: uma psicanálise possível. Estilos Clín. 2017;22(1):64-82. https://doi.org/10.11606/ issn.1981-1624.v22i1 p64-82

6. Lacan J. O Seminário, livro 4: a relação de objeto. Rio de Janeiro: Jorge Zahar; 2004. 456 p.

7. Torezan ZCF, Aguiar F. O sujeito da psicanálise: particularidades na contemporaneidade. Rev Mal-estar Subj [Internet]. 2011 [cited 2020 Sep 17];11(2):525-54. Available from: https://periodicos.unifor.br/rmes/article/view/4993

8. Lefort R. Nascimento do Outro. Salvador: Fator; 1984. 305 p.

9. Santos VLA, Almeida FA, Ceribelli C, Ribeiro CA. Understanding the dramatic therapeutic play session: a contribution to pediatric nursing. Rev Bras Enferm. 2020;73(4):e20180812. https://doi.org/10.1590/0034-7167-2018-0812

10. Kaszubowski E, Aguiar F. O registro imaginário nos antecedentes lacanianos. Agora (Rio J.). 2015;18(1):85-100. https://doi.org/10.1590/ S1516-14982015000100007 